\title{
Mimesis - między udawaniem a referencją*
}

\begin{abstract}
Mitosek Zofia, Mimesis - między udawaniem a referencją [Mimesis - between pretending and reference]. „Przestrzenie Teorii” 1, Poznań 2002, Adam Mickiewicz University Press, pp. 25-46. ISBN 83-232-1238-4. ISSN 1644-6763.

This study reformulates the old problem of mimesis in the spirit of pragmatics. It treats similarity as as a subjective-objective relation. Comparison of the conception of formal mimetism and literature as pretending of actual acts of speech leads to a conclusion on the asymmetry of these two modern applications of the category of mimesis. The first one attempts at restricting its use, the second attempts at globalisation, a kind of which is pragmatisation. Conception of mimesis as pretending strengthens the objective characterisation of categories. The function of convention is emphasised, which determines either the mimetic or referential reading of a text, which becomes particularly important in the reading of documentary and paradocumentary literature where we have to do with a permanent asymmetry of the sender's expectations and of the recipient's reactions. Attempts at defining mimesis in terms of cognitivist theories are conducive to pragmatisation of categories where the mental effects of a literary representation are involved, and the similarity is defined as closeness of a text and perceptual schemes located in the recipient's brain. All these processes lead to the questioning of mimesis as a palpable property in the structure of the text, stressing the reader's and the reading's role in the constitution of the mimetic effect.
\end{abstract}

„W tym miejscu stał dom, w którym mieszkał w latach 1878-1879 STANISŁAW WOKULSKI, postać powołana do życia przez Bolesława Prusa w powieści Lalka, uczestnik powstania 1863 roku, były zesłaniec syberyjski, obywatel m.st. Warszawy, filantrop i uczony, urodzony w r. 1832" - tak wygląda napis na tablicy umieszczonej na budynku pod adresem Krakowskie Przedmieście 4/6. Tablica jest rzeczywista, ale mówi o zdarzeniu fikcyjnym. Naśladuje liczne w tej okolicy inskrypcje mówiące o zdarzeniach prawdziwych: jest pełna autentycznych dat i faktów. Poza Stanisławem Wokulskim, postacią „powołaną do życia” do życia w powieści, która/y jednak - postać czy człowiek? - urodził się w roku 1832. Ta śmieszna trudność gramatyczna sygnalizuje nieskończone ambiwalencje, przed którymi staje podmiot - co najmniej poczwórny: przechodzień z Krakowskiego Przedmieścia - czytelnik tablicy, czytelnik Lalki, znawca historii literatury polskiej i w końcu ja - soit dit "znawca mimesis". Wahanie gramatyczne to wahanie mimetyczne: o co w istocie chodzi? czy postać to człowiek? Autor tablicy, w sposób nieświadomy, stworzyl tekst metafikcyjny, w którym rzeczywistość literacka miesza się z refleksją o niej,

"Jest to tekst referatu wygloszonego na XXX Konferencji Teoretycznoliterackiej w Krasiczynie (9-15 IX 2001), zorganizowanej przez Pracownię Poetyki Historycznej IBL PAN. 
i który w tym pomieszaniu odtwarza sytuację odbiorcy pogrążonego w trwający nieprzerwanie od czasu publikacji Lalki proces mimesis.

Samo wahanie pojawia się w punkcie wyjścia tej pracy. Pisać dzisiaj o tej kategorii to sprawa beznadziejna. Cóż nowego można powiedzieć w sytuacji, kiedy funkcjonuje ona w obrębie rodziny pojęć takich, jak prawdopodobieństwo, fikcja, realizm, przedstawienie, reprezentacja, uobecnienie - żeby wyliczyć tylko kilka. Kiedy czyta się ostatnio opublikowane książki z tej domeny, takie jak Mimesis as make-believe Kendalla Waltona (1990), Fiction et diction Gérarda Genette'a (1991), Powieść i prawdopodobieństwo Anny Martuszewskiej (1992), Tekstowy świat Ryszarda Nycza (1992), De la représentation Louis Marina (1994), Teorie powieści za granicq Henryka Markiewicza (1995), Pourquoi la fiction Jean-Marie Schaeffera (1999), Pragnienie obecności Michała P. Markowskiego (1999), The Distincion of Fiction Dorrit Cohn (1999) czy wreszcie ciepłą jeszcze pracę Anny Łebkowskiej Między teoriami a fikcją literacką (2001), to okazuje się, że wszystkie one zawierają pytania o mimesis, referencję, kreację, zmyślenie, modelowanie, wyobraźnię, poznanie, w końcu - o rzeczywistość. Czy należy powtórzyć heroiczny wysiłek Łebkowskiej, która omówiła najnowszą teorię literatury, przyjmując za centrum problemowe fikcję? Czy obserwować ruch badawczy w obrębie mimesis, mnożąc znaki zapytania, od których roiła się moja książka? Czy wreszcie ograniczyć się do doświadczeń literackich, pozostawiając na boku naukę o nauce?

Spróbuję jeszcze raz spojrzeć na to wszystko, nad czym zastanawiam się od kilkunastu lat. Zacznę od tytułowej opozycji. Mówić o mimesis w kontekście referencji, to zakładać, że dzieło sztuki naśladuje, odtwarza, reprodukuje coś, co jest od niego inne, co posiada niezależny odeń status egzystencjalny, coś, co estetyka nazywa modelem. Udawanie przeciwstawia się naśladowaniu: podmiot symuluje jakieś działanie, bawi się, gra, wytwarzając w swojej grze coś, czego przedtem nie było: pozór, simulacrum, byt, o którym można by co najwyżej sądzić, że jest do czegoś podobny. Pisząc: mimesis - między udawaniem a referencją, celowo zawieszam opozycję; skupiam uwage na wahaniu odbiorcy artystycznego przedstawienia, który - świadomy tego, że ma do czynienia z rzeczywistością wytworzona, pozorną, nową, sztuczną - daje się porwać owemu pozorowi i chcąc nie chcąc odnosi go do rzeczywistości bliskiej sobie.

Występująca w tytule para pojęć komplikuje się na tle tendencji, które ostatnio pojawiły się w myśleniu o mimesis. Chodzi o wzajemnie sprzeczne postawy badawcze, które określam jako globalizację i ograniczenie użycia antycznej kategorii. Następnie - o rozróżnienie mimesis jako przedstawienia rzeczywistości oraz mimesis jako naśladowania mowy.

Ujęcia globalizujące stosują termin mimesis do określenia wszelkich relacji między literaturą a światem od niej niezależnym, wciągając w jego 
zakres tyleż realistyczne przedstawienie, co alegoryczną figurację i metafikcyjną prozę. W mniejszym lub większym stopniu wywodzą się one od książki Ericha Auerbacha, której tytuł brzmiał: Mimesis. Rzeczywistość przedstawiona $w$ literaturze Zachodu (1946). Próby ograniczenia zakresu kategorii odwołują się do takich cech, jak podobieństwo, odpowiedniość czy analogia świata przedstawianego i przedstawiającego, wykluczając arbitralność, abstrakcję czy fantastykę. Tu jednak to, co wydawało się od dawna oczywiste, wcale oczywiste nie jest. Weźmy na przykład podobieństwo. Kiedyś pisałam: „Mimesis to czynność lub zabieg, w wyniku którego jakiś przedmiot czy zachowanie zawiera w swojej materii pewne aspekty formy innego przedmiotu lub zachowania, istniejącego wcześniej i w innej materii" ${ }^{\prime}$. Już w rozważaniach o ikoniczności okazało się, jak bardzo owa definicja nie odpowiada ruchowi mimesis; jako relacja dwóch przedmiotów podobieństwo wymaga podmiotu, który ją stwierdza. Uwzględnienie czynnika podmiotowego w konstatacji mimesis radykalnie przemieszcza obiekt badań ze struktury przedmiotu „naśladujacego" na konteksty pozaartystyczne, takie jak smak, sytuacja, wiedza odbiorcy ${ }^{2}$.

Przesunięcie mimesis ze sfery semantyki w sferę pragmatyki niepomiernie poszerza jej zakres: jeśli mimetyczność jest grą podmiotów zaangażowanych w komunikację artystyczną, wówczas nie ma mowy o uchwytnych wskaźnikach tego fenomenu. Mimetycznie, to znaczy w relacji do rzeczywistości, można odbierać powieść Prusa, jak i obraz Paula Klee; z kolei wiersz opisujący pejzaż można uznać za wytwór fantazji, a Widok

${ }^{1}$ Z. Mitosek, Mimesis. Zjawisko i problem, Warszawa 1997, s. 17. W trakcie pisania tej książki skupialam uwagę na problemie podobieństwa, czego efektem bylo swoiste ustatecznienie fenomenu mimesis. Tłumacząc antyczny termin zgodnie $\mathrm{z}$ etymologia jako naSladowanie, szukałam jego przejawów w strukturze zachowań i artefaktów. Głównym problemem było naśladowanie rzeczywistości niejęzykowej w dyskursie językowym. Postawa semiotyczna doprowadziła mnie do istotnych restrykcji: pisałam o motywacji naturalnej w znakach poetyckich, zajmowałam się mimetyzmem formalnym. Najpewniejszym rozwiązaniem wydała mi się kategoria ikoniczności. Kwestie takie, jak przedstawienie czy modelowanie swiata, wykreśliłam z pola badań lub postawiłam pod znakiem zapytania. Gest ograniczenia kategorii do opisu ściśle określonych zjawisk nie pozbawiony był jednak dwuznaczności. Mimesis jawiła mi się ostatecznie jako powszechna intertekstualność, co odpowiadałoby tezom dekonstrukcjonistów o „tekstowym świecie" i o literaturze, która jest wieczną grą na języku. $\mathrm{Z}$ autoironią mogę powiedzieć, że ostre kryteria metodologiczne skończyły się w tej książce pewną filozofią czy ideologią literatury. „Wprowadzenie perspektywy zasadniczej i szerokiej”, której domagała się ode mnie Ewa Szary-Matywiecka (,Pamiętnik Literacki" 1999, z. 3), to w chwili obecnej tyleż namysł nad zagadnieniami przedstawienia czy mowy, co - i przede wszystkim - ujęcie mimesis jako procesu, operacji autorsko-czytelniczej.

${ }^{2}$ N. Goodman owa transformację stanowisk streszcza w paradoksalnym pytaniu Kiedy sztuka?. Por. N. Goodman, Jak tworzymy świat, przeł. M. Szczubiałka, Warszawa 1997. Por. także A. Minazzoli, La premiere ombre, reflexion sur le miroir et la pensée, Paris 1990. 
Delft Vermeera traktować - niczym Proustowski Swann - jako układ barw.

W tym momencie energicznie wkroczą zwolennicy uściślenia i ograniczenia terminu. Są to na ogół literaturoznawcy i nieprzypadkowo, bowiem to literatura zdaje się dostarczać nie kwestionowanych dowodów na podobieństwo. Tekst literacki - nawet jeśli przedstawia świat - naśladuje tylko fakty werbalne. Przedmiotem imitacji staje się to, co uważane było dotąd za jej środek - mowa. Zjawisko mimetyzmu formalnego, jako „naśladowania środkami danej formy innych form wypowiedzi, form literackich, paraliterackich, pozaliterackich oraz [...] tych lub owych postaci potocznego kontaktu językowego" jest dobrze rozpoznane i wyodrębnione w teorii prozy ${ }^{3}$. Ta precyzyjna definicja bardzo ogranicza zakres literackiej $m i$ mesis, za to przykłady jej działania są niewątpliwe, pewne.

Czy rzeczywiście pewne? Znamy granice mimetyzmu formalnego, ale jeśli powiemy, że jest on odmianą mimetyzmu komunikacyjnego, zakres pojęcia niebezpiecznie się poszerza. Chodziłoby o naśladowanie $w$ tekstach „niepragmatycznych” strategii komunikacyjnych ukierunkowanych pragmatycznie. Mówi się także o mimetyzmie metodologicznym czy epistemologicznym ${ }^{4}$. Paradoksalne jest to, że ostatnie badania nad dziejopisarstwem wykazują jego znaczną zależność od narracji literackiej ${ }^{5}$. Metafory epistemologiczne działają zatem w obydwie strony. Zaś próba ograniczenia mimesis, oparta na szukaniu w literaturze śladów mowy nieliterackiej, spali na panewce.

Pretekst dla uniwersalizacji fenomenu mimesis stworzyła filozofia analityczna. Chodzi o teorię aktów mowy, której twórcy twierdzą, że

\footnotetext{
${ }^{3}$ Mimetyzm formalny jest kategorią wprowadzona przez M. Głowińskiego. Por. studium O powieści w pierwszej osabie (1969), w: Narracje literackie i nieliterackie, Kraków 1997, s. 57. Artykuł ten zrobił światową karierę, opublikowany został w języku czeskim i angielskim, przedrukowało go $\mathrm{m}$. in. francuskie pismo „Poétique” 1978, t. 72. Wielokrotnie odwołuje się do niego G. Genette.

${ }^{4} \mathrm{O}$ mimetyzmie komunikacyjnym pisze $\mathrm{K}$. Bartoszyński: przedmiotem jego badań są strategie przechodzenia od opowieści i rozmowy do narracji. Chodzi o zabiegi takie, jak zmiana form deiktycznych, dystrybucja informacji, jej nadmiar czy eliptycznosć oraz pozycja podmiotu mówiącego, jakim jest w powieści narrator. Gra tegoż narratora $\mathrm{z}$ adresatem jego wypowiedzi, gra wypowiedzi postaci z mową narratora może być oceniona jako jedna $z$ form interakcji społecznej, jej świadectwo czy projekt. Por. K. Bartoszyński, Opowiadanie a deixis i presupozycja (1982), w: Teoria $i$ interpretacja, Warszawa 1985. Na temat naśladowania przez utwory fikcyjne wypowiedzi historycznej pisał także G. Genette w: Fiction et diction, Paryż 1991. Koncepcja "mimetyzmu metodologicznego" nawiązuje do uwag U. Eco na temat występującej w sztuce "metafory epistemologicznej”, czyli podejmowania paralelnych do nauki dylematów poznawczych. Por. K. Bartoszyński, Zagadnienie komunikacji literackiej $w$ utworach narracyjnych (1971), w: Teoria $i$ interpretacja oraz U. Eco, Dzielo otwarte. Forma i nieokreśloność, przel. J. Gałuszka, Warszawa 1973.

${ }^{5}$ Por. H. White, Poetyka pisarstwa historycznego, przeł. i red. E. Domańska i M. Wilczyński, Kraków 2000.
} 
tekst literacki stanowi jedno z nietypowych użyć języka - udaje procesy wypowiadania, akty mowy, a siła i specyfika literatury polega na fingowanej performatywności. Udawanie czy naśladowanie czynności illokucyjnych jest wyznacznikiem fikcji jako takiej, a skoro tak, to nie ma już mowy o ograniczaniu mimesis do pewnych specjalnych wypadków i struktur ${ }^{6}$. John Searle stwierdził: „Nie ma żadnej właściwości samego tekstu, semantycznej czy syntaktycznej, która pozwoliłaby na zidentyfikowanie danego tekstu jako dzieła fikcyjnego"?

Zastosowanie teorii aktów mowy do literatury wywołało żywe i do dziś niepokonane opory ze strony strukturalistów. Zdawać by się mogło, że mimetyzm formalny i językowy stanowi wyjątkowo dobitną realizację tezy o fingowanych w literaturze aktach mowy. Ale Michał Głowiński i Gérard Genette (a wcześniej Käte Hamburger) pokazują cała masę utworów literackich, którym nie da się w żaden sposób przypisać wzorca naśladowania, jakim byłaby żywa mowa. Owe dewiacje ujawniają się w większości tekstów artystycznych, wobec czego globalne przekonanie o mimetycznym statusie każdej wypowiedzi literackiej jest nie tylko mylne, ale prowadzi do zatarcia swoistości artystycznej utworów, w których mimesis formalna i językowa stanowi znaczący chwyt literacki ${ }^{8}$.

Polemiki takie są rezultatem permanentnych nieporozumień, które prowokuje wieloznaczność kategorii mimesis. Trzeba przede wszystkim powiedzieć, że dla badaczy aktów mowy język jest przedmiotem logiki, a nie poetyki. Nie piszą o naśladowaniu innych form wypowiedzi, ale o udawaniu „poważnego" aktu wypowiadania. Zajmując się funkcją, a nie substancją wypowiedzi, konsekwentnie przemieszczają problem mimesis ze sfery stylistyki i semantyki $\mathrm{w}$ domenę pragmatyki ${ }^{9}$. $\mathrm{O}$ ile koncepcja

${ }^{6}$ J. S. Searle, Status logiczny wypowiedzi fikcyjnej (1975), przeł. H. Buczyńska-Garewicz, w: Studia z teorii literatury. 1, Archiwum przekladów "Pamiętnika Literackiego", Wrocław 1988. Należy podkreślić, że uwaga ta odnosi się do wypowiedzi fikcyjnej, a nie do wypowiedzi literackiej. Według Searle’a fikcyjność tekstu jest konstytuowana przez intencję autora, natomiast literackość - przez akt percepcji. Zakresy pojęcia fikcji i literatury nie pokrywają się, mogą się tylko krzyżować. Postawę taką, niezależnie od pism analityków, Janusz Lalewicz nazywa mimetyzmem konstytutywnym. Por. J. Lalewicz, Mimesis jezykowa a problem naśladowania w literaturze, w zbiorze: Tekst i fabuta, red. Cz. Niedzielski, Wrocław 1979.

${ }^{7}$ J. Searle, op.cit., s. 29.

${ }^{8}$ Por. K. Hamburger, Die Logik der Dichtung, Stuttgart 1968; M. Głowiński, Mimesis jezykowa w wypowiedzi literackiej (1980), w: Narracje literackie i nieliterackie; G. Genette, Fiction et diction.

${ }^{9} \mathrm{O}$ obecności mimesis w tekście decyduje umowa, która stworzyła instytucję literatury. Paradoksalny byt tej instytucji dobitnie określil Jacques Derrida: „Nie zawieszając lektury transcendentnej, lecz zmieniając swoje nastawienie do tekstu, zawsze można na nowo wpisać w przestrzeń literacką jakikolwiek tekst - gazetowy artykuł, teoremat naukowy, strzęp rozmowy. Chodzi więc o funkcję literacką i literacką in ten cjonalność, doświad- 
mimetyzmu formalnego zakładała, że utwory literackie imitują pewne istniejące w praktyce mowy style, a zatem, że w ich strukturze można odnaleźć ślady potocznych form wypowiedzi, a same te formy stanowią ich referencję, to analitycy pisząc o udawaniu aktów mowy, nie interesują się modelem, jakim byłby określony styl: przedmiotem ich badań nie jest budowa tekstu, ale interakcja towarzysząca jego wypowiadaniu. W tym sensie ich aksjomaty nie dają się weryfikować empirycznie - co zarzuca im $\mathrm{np}$. Głowiński. Interesuje ich proces i sytuacja fingowania w wymiarze antropologicznym oraz społecznym. Searle niechętnie używa słowa mimesis. Pisząc o udawaniu jako intencji podmiotu, podkreśla aspekt „niemylącego pseudowykonania”; tym samym wprowadza kwestię konwencji gwarantujących, że odbiorca (czytelnik) fikcyjnych aktów mowy nie potraktuje ich serio. John Austin stwierdził, że tym, co odróżnia udawanie od naśladowania, grania, odbywania próby, imitowania nie jest intencja, ale cel i publiczny charakter ${ }^{10}$.

Kategoria mimesis pojawia się w pracach Richarda Ohmanna i Barbary Herrnstein-Smith; Michał Głowiński i Gérard Genette formułują swoje polemiki, odnosząc się do ich studiów. W ujęciu Ohmanna mimesis to współdziałanie tekstu i odbiorcy, operacja w trakcie której czytelnik, opatrzony w znajomość konwencji, percypuje wypowiedź literacką jako mowę „podwojoną" i dopiero potem buduje obraz świata implikowanego przez akty illokucyjne pisarza ${ }^{11}$.

czenie, a nie (przyrodzoną czy ahistoryczną) istotę literatury. Istota literatury, jeśli zgodzić się, że słowo to posiada jakąś istotę, zostaje wytworzona jako zbiór obiektywnych reguł w osobliwej historii «aktów» inskrypcji i lektury". Por. J. Derrida, Ta dziwna instytucja zwana literatura (1989), przel. M. P. Markowski, „Literatura na Świecie” 1998, nr 11-12, s. 190-191. Funkcjonalność pojęcia literatury została już dawno odkryta przez formalistów i omówiona dokladnie w pracach J. Tynianowa. Niezależnie od formalizmu stała się ona przedmiotem gruntownej refleksji w fenomenologii R. Ingardena, który za kryterium literackości uznawał fikcyjny charakter zdań w dziele literackim - quasi-sądów. Kwestiom zbieżności między poglądami Ingardena $\mathbf{i}$ angielską filozofią analityczną poświęciła całą książkę D. Ulicka. Por. Granice literatury $i$ pogranicza literaturoznawstwa. Fenomenologia Romana Ingardena $w$ świetle filozofii lingwistycznej, Warszawa 1999. Uznając sprawę za rozwiązaną, nie będę powracala w tej pracy do propozycji Ingardena. Muszę jednak lojalnie wyznać, że prawie wszystkie problemy, o których piszę w tej pracy, zostały w latach trzydziestych XX wieku zasygnalizowane przez Ingardena, który terminem mimesis posługiwał się tylko w studium Uwagi na marginesie „Poetyki” Arystotelesa (1946), w: Studıa $z$ estetyki, t. 1, Warszawa 1958.

10 „Aby udawać, w podstawowym przypadku, muszę próbować sprawić, by inni wierzyli, lub wywrzeć na nich wrażenie, za pomocą doraźnego osobistego działania w ich obecności, że jestem (rzeczywiście, wyłącznie itd.) abc - po to, aby ukryć fakt, że w rzeczywistości jestem xyz". J.L. Austin, Udawanie (1953), w: Mówienie i poznawanie. Rozprawy i wyklady filozoficzne, przeł. J. Woleński, Warszawa 1993, s. 353-354.

${ }^{11}$ R. Oh mann, Literatura jako akt oraz Akty mowy a definicja literatury, przeł. B. Kowalik i W. Krajka, „Pamiętnik Literacki” 1980, z. 2; B. Herrnstein-Smith, Poezja i mowa, przeł. P. Czapiński, „Pamiętnik Literacki” 1989, z. 4. 
Jeżeli można by szukać w teorii aktów mowy praktycznych zastosowań dla literaturoznawstwa, to byłaby to historia recepcji czy komunikacja literacka, pojmowana jednak nie tyle jako adekwatność kodów nadania i odbioru, ale jako wyzwanie i reakcja odbiorcy. Akty mowy, także te, które - jak w literaturze - mają charakter fingowany, dysponują mocą performatywną, stąd przedmiotem badania staje się dzialanie tekstu. Odbiór można interpretować jako przedłużenie procesu udawania, a odbiorcę jako osobnika, który wierzy czy tylko udaje, że wierzy w to, co zostało w literackiej wypowiedzi za obopólną zgodą udane. W kontekście tych problemów mimesis odzyskuje swój pierwotny antropologiczny wymiar.

Grą w udawanie nazwal mimesis Kendall Walton. Modelem takiej gry nie jest komunikacja językowa, ale zabawa dziecięca, w której rekwizytami stają się przypadkowe przedmioty, a główny efekt polega na utożsamieniu się $\mathrm{z}$ przyjętymi lub nadanymi rolami i jednoczesnym dystansie, wynikającym ze świadomości udawania. Kategoria gry przyznaje odbiorcy dzieła sztuki rolę partnera. Jest to jednak partner szczególny, gotowy do uwierzenia w to, w co umowa zabrania mu wierzyć. Ambiwalencja utożsamienia i dystansu określa efekt mimetyczny; w literaturze naznaczony jest on przez szczególną emocję, jaką jest pragnienie „bycia porwanym przez opowieśc"12.

Mimesis jako udawanie podlega regułom wszelkiej gry, takim jak dobrowolność, wyodrębnienie (gra zamknięta jest w granicach przestrzenno-czasowych), element niepewności, fikcyjność, a przede wszystkim umowność ${ }^{13}$. W wypadku gry literackiej mamy do czynienia $\mathrm{z}$ paradoksem: jeśli jednym z czynników określających grę jest fikcyjność, to mimesis jako element określany pozostaje zarazem warunkiem elementu określającego, tzn. fikcji. Paradoks ten jest jedną z bardziej znanych aporii estetyki. Bardziej istotna jest sprzeczność o charakterze praktycznym. Fikcyjność jest efektem intencji autora, ale jej rozpoznanie zależy od sto-

${ }^{12} \mathrm{~K}$. Walton, Mimesis as Make-Believe. On the Foundations of the Representational Arts, Cambridge, Massachusetts, London 1990, s. 241. Walton analizuje także teksty literackie, które stawiają opór emocjonalnym lekturom, gdzie wyeksponowane konwencje, takie jak np. mise en abyme, potęgują dystans i zwrócenie uwagi na spektakl, jakim jest naśladowanie. Mimo że Walton polemizuje z teorią aktów mowy za jej ograniczenie do sztuki literackiej, zwraca uwage na przemieszczenie języka ze środka przedstawienia na jego obiekt. Por. A. Łebkowska, Między teoriami a fikcjq̨ literackq, Kraków 2001.

${ }^{13}$ R. Caillois, Ludzie a gry $i$ zabawy, Żywiol $i$ lad, przel. A. Tatarkiewicz, Warszawa 1973, s. 306. Na związek mimesis językowej z opisywaną przez Caillois grą w mimicry zwrócił uwagę J. Lalewicz we wzmiankowanej wcześniej rozprawie. Pojęcie gry, szeroko stosowane w badaniach nad komunikacją literacką, do badań nad mimesis zastosował m.in. U. Rapp. Por. Simulation and Imagination. Mimesis as Play, w: Mimesis in Contemparary Theory, volume 1, red. M. Spariosu, Philadelphia/ Amsterdam 1984. 
pnia opanowania konwencji przez czytelnika. Nie zawsze ów stopień jest symetryczny. Fenomenologia i teoria aktów mowy skłonne są przyznawać jej nieznajomość naiwnemu czytelnikowi, który literacką, kreowaną quasi-rzeczywistość bierze za świat realny. Ale zdarza się, że naruszenie umowy bywa celową manipulacją ze strony autora. Warto tu przytoczyć dwa przypadki z tej dziedziny. Niemiecki pisarz, Wolfgang Hildesheimer - twórca książki o Mozarcie - napisał fikcyjną biografię człowieka o imieniu Marbot, która tak znakomicie udawała autentyk, że skłoniła czytelników do poszukiwań bohatera opowieści. Inną głośną aferą była niedawna publikacja książki Binjamina Wielkomirskiego Bruchstucke. Aus einer Kindheit 1939 - 1948, której autor podał się za niedoszłą ofiarę Holokaustu ${ }^{14}$.

I w jednym, i w drugim wypadku mamy do czynienia $z$ udawaniem, którego narzędziem jest m.in. mimetyzm formalny (naśladowanie autentycznej biografii, imitacja autobiografii $)^{15}$. Stanowił on pułapkę dla czytelników. Eksperyment z Marbotem udał się dzięki temu, że naśladowanie stylu dokumentu zostało wzmocnione przez mimesis pragmatyczną: o recepcji książki jako literatury faktu zadecydował akt mowy, jakim był podtytuł „biografia”. Autor złamał umowę dotyczącą granicy między autentykiem a fikcją, udał, że mówi serio, nie podając żadnego sygnału udawania i stwarzając tym samym alibi dla zabawy. W wypadku Wielkomirskiego akt udawania służył celom odmiennym niż sztuka: jego książkę potraktowano jako oszustwo. Ale, jak pokazuje Caillois: „Oszust nie wykracza poza świat gry. Sprzeniewierzając się regułom, udaje jednak, że ich przestrzega. Stara się zachować pozory. Jest nieuczciwy i zarazem obłudny. Poprzez swą postawę potwierdza niejako prawomocność konwen-

${ }^{14}$ Por. W. Hildesheimer, Marbot. Eine Biographie, Frankfurt 1981, Surkampf Verlag. Bliżej na ten temat piszą J. - M. Schaeffer w książce: Pourqoui la fiction, Paris 1999 oraz D. Cohn w książce: The Distinction of Fiction, Baltimore 1999. Można sądzić, że twórca tablicy upamiętniającej Wokulskiego byłby naiwnym czytelnikiem Marbota, a pozycję Hildesheimera zajmuje uczony czytelnik tablicy, który śmieje się i z naiwności jej autora, i nieuwagi jej przeciętnych czytelników (także autorów książek, takich jak Warszawa $w$ "Lalce" Prusa). Sprawa jest jednak bardziej skomplikowana: autor tablicy wiedział, że Wokulski był „postacią powołaną do życia przez Bolesława Prusa” (tak jak Hildesheimer w wywiadach dotyczących swojej quasi-biografii twierdzil, że „dał życie Marbotowi”), a jednoczesnie przekazywal wszystkie daty i fakty historyczne typowe dla postaci autentycznej. Kiedyśs skłonna byłam ich sytuację interpretować jako paranoiczną (por. Z. Mitosek, Mimesis, s. 255). Dzisiaj w napisie widzę wszystkie sprzecznosci, które zamykają się w akcie mimesis pojętym jako niekończąca się lektura. Informację o książce Wielkomirskiego Bruchstucke. Aus einer Kindheit 1939-1948, Suhrkamp Taschebuch 1998, uzyskałam od Michała Głowińskiego. Na temat tej mistyfikacji pisze Maria Janion w książce: Żyjq̨c tracimy życie, Warszawa 2001, s. 405-409. Bruno Dossekker (prawdziwe nazwisko autora Bruchstucke) nie jest Żydem, urodził się po wojnie, w Szwajcarii.

${ }^{15}$ Schaeffer, omawiając mechanizmy komunikacyjne Marbota, powołuje się na pracę Głowińskiego. 
cji, które narusza, potrzebuje bowiem, aby inni ich przestrzegali. Jeśli wpadnie - "przepędzą go". Świat gry i zabawy nie jest narażony na szwank"16.

Przykłady te prowokują nowe pytanie: jaki jest cel udawania? John Austin, badając ten antropologiczny fenomen, zwracał uwagę nie tylko na to, co podmiot udający chciałby w swoim zachowaniu odsłonić, a co przez to zachowanie ukrywa. Jest to problem maski, która - jak pisał Derrida "tyleż ukrywa, co odsłania naturę physis"17.

Odpowiedź badaczy sztuki zgadza się z pierwotną kantowską interpretacją gry: jest to działalność autoteliczna, rodzaj celowości bez celu, wyczerpująca się w samej przyjemności grania. Filozofia analityczna, podejmując tematykę gry i zastanawiając się nad różnymi typami gier językowych, odsuwa problem samocelowości na korzyść refleksji nad ich performatywnym charakterem i towarzysząca im interakcją. Ta właśnie interakcja wciaga odbiorcę w świat przedstawiony, powodując, że utwór jako literacki spektakl języka staje się dla niego spektaklem świata, który ów język przedstawia ${ }^{18}$.

Mimo że według badacza instytucja literatury opiera się na wielopoziomowej fikcji (fundowanej przez wielopoziomową mimesis), czytelnik pytając o to, co udaje literatura, „wyskakuje” $\mathrm{z}$ reguł gry: zdarza mu się oglądać figurę konika szachowego jako rzeźbę prawdziwego konia. Zda-

${ }^{16}$ Caillois, op. cit., s. 349. Interesujące uwagi na temat związku falszerstwa z mimesis poczynił R. Nycz w Tezach o mimetyczności: „Powiada się zazwyczaj, że falsyfikat jest tylko «fasadą", gdyż jego wytwórca pragnie naśladować gotowy obiekt z pominięciem złożonych faz autentycznego procesu tworzenia. Uwaga ta jest jawnie nietrafna, gdyż falsyfikat sensu stricto to falsyfikat bez przedmiotowego wzorca ( $w$ literaturze to regula - klasycznymi przykładami są tu utwory Hanki i Macphersona), pozwala jednak sobie uprzytomnić, że dla tego rodzaju fałszerza o artystycznej prawdzie obiektu stanowi udział jego formalnych znamion w obiektywności systemu reprezentacji, który ma charakter "naturalny", niezależny od wszelkich zmian w historycznym kontekście. Bycie obrazem przysługuje tu obiektowi na mocy jego wewnętrznych jakościowo-strukturalnych własności i zarazem - zgodnie $z$ jego statusem jako podobizny czy obrazu - wskazuje na istnienie pierwowzoru w postaci przynajmniej kategorialnej, ogólnego prawa przedstawienia”. (R. Nycz, Tekstowy świat, s. 249-250).

17 J. L. A ustin, Udawanie, s. 344; J. Derrida, La Dissemination, Paris 1972, s. 210.

${ }^{18}$ Ow interakcyjny charakter naśladowania aktów mowy podkreśla w swoich pracach R. Ohmann, opierając się na koncepcji literatury zaangażowanej J. P. Sartre'a. Nie jest zupelnie pewne, czy w pracach Ohmanna termin mimesis dotyczy naśladowania aktów illokucyjnych, czy skonstruowanego - implikowanego przez te akty świata. Mimo że badacz wspomina o formach literackich udających potoczną konwersację (co jest istotą dramatu jako jedynego rodzaju konsekwentnie mimetycznego) czy wierszach udających podręczniki szkolne, to zdecydowanie bardziej interesuja go formy pragmatycznie dewiacyjne. Nie dlatego jednak, że obalają one przyjęty przez analityków aksjomat, ale dlatego, że działają na zasadziє obalania tej mimesis, która tkwi w czytelniku jako zespól konwencji: nie tylko literackich czy językowych, ale także stereotypów i ideolgemów. 
rza mu się traktować zawarte w dziele akty mowy jako preskrypcje i wcielać w życie ich illokucyjną zawartość, co powoduje istotne przesunięcie fenomenu mimesis. Dzieło nie tyle odtwarza wcześniejszy model, co samo staje się modelem zachowań realizowanych przez nazbyt gorliwych - jak Don Kichot czy Emma Bovary - czytelników. Problem życia jako naśladowania sztuki doczekał się wielu socjologicznych opracowan ${ }^{19}$.

Asymetria intencji autora i czytelnika ujawniła się przy odbiorze praktyk paradokumentalnych. Praktyki te powodują powrót wszystkich dylematów związanych z mimesis. Fala dokumentaryzmu, która zalała literaturę drugiej połowy XX wieku, stawia czytelnika w sytuacji nieustannego wahania. Nikt z badaczy nie wątpi, że np. Pamiętnik z powstania warszawskiego Mirona Białoszewskiego jest literatura, i to wysokiej klasy. Ale potoczny czytelnik może zwątpić, może „gadaninę” Biłoszewskiego przyjąć jako autentyczny język wyznania ${ }^{20}$. Mowa Pamiętnika jest stylistycznie nacechowana, jak jednak odczytać pisane „intelektualną" prozą Fantomy Kuncewiczowej? Jako ekspresję czy też jako świadomy siebie efekt pracy literackiej? Ale co wiemy o tej pracy na podstawie fragmentów, które pisarka wybrała jako formę przedstawienia? Czy da się tu zastosować teza analityków, że autorka naśladuje akt pisania autobiografii, kiedy w potoku luźnych asocjacji gatunek autobiografii świadomie rozbija? Czy robi to jak romantycy, w „imię prawdy życia”, czy - jak to zinterpretowała jedna $z$ moich studentek - w imię nowej literatury, zrywającej $\mathrm{z}$ utrwalonymi literacko formami przekazu? ${ }^{21}$ Philippe Lejeune podkre-

${ }^{19}$ Por. R. Girard, Mensonge romantique et vérité romanesque, Paris 1961. Inspiracje Girarda, zwłaszcza te dotyczące roli literatury w mimetycznej mediacji i konsekwencji trójkąta mimetycznego dla badań nad tropami rozwija E. Gans w ksiązce: Signes of Paradox. Irony, Resentement and Other Mimetic Structures, Stanford 1997. Por. także M. Picard, La lecture comme jeu, Paris 1986, rozdział L'Illusion.

${ }^{20}$ Por. recenzję W. Żukrowskiego z Pamiętnika. Dostrzegając stylizację mowy narratora na język zagubionego w mieście dziecka, krytyk traktuje ów chwyt jako sztuczna próbę udziwnienia; „uparty a miejscami bardzo sztuczny infantylizm zapisu” fałszuje według niego nie tylko prawdę o powstaniu, ale i o przeżywającym go 17-letnim człowieku. Por. W. Żu krowski, Mironek na wojnie, „Nowe Książki” 1970, nr 19. Odbiegając od ocen etycznych, można spytać, czy mimetyzm językowy i formalny służył w książce Białoszewskiego celom literackim, czy też stanowił świadomą, chociaż utopijną próbę artykulacji doświadczenia nastolatka sprzed ćwierćwiecza przez człowieka dorosłego? Tu pojawia się problem, który nie jest tematem tej pracy: chodzi o styl jako wyznacznik literackości.

${ }^{21}$ Warto wspomnieć o wątpliwościach dotyczących kwalifikacji literackiej dziela Prousta; ostatnio ujawniły się one w fundamentalnej pracy J. Kristevej, Le Temps sensible, Paris 1994. Utwór ten traktowany jest w całej książce jako modelowa realizacja powiesci „bachtinowskiej” (dialogizm narracyjny, wieloglosowośc i wielowartościowosć), ale na koń cu Kristeva wyznaje, że pisząc swoją przyszłą autobiografię: „Je ne deurais pas me soucier que de ma mémoire involontaire et éventuelle de la mise en forme. Mais Proust l'a déjà fait, et j'ai choisi de l'accompagner" (s. 397). D. Cohn w artykule L'ambiquite générique de Proust, 
śla, że nie istnieją czysto stylistyczne wyznaczniki autobiografii (tak jak Searle stwierdził, że nie istnieją stylistyczne wyznaczniki fikcji); Lejeune pisze o kontrakcie wypowiedzeniowym (contrat énonciatif), sygnalizowanym na karcie tytułowej książki ${ }^{22}$. Jak jednak traktować utwory bez takiego paratekstu albo zawierające - jak w wypadku Marbota - paratekst zmyłkowy?

Inny przykład to Cesarz Ryszarda Kapuścińskiego, tekst dokumentalny, w którym autor z powodzeniem naśladuje technikę opowieści w opowieści, co powoduje, że reportaż o rewolucji w Etiopii czyta się jako doskonałą literaturę. I znów asymetria, co najmniej potrójna: serio akt mowy, jakim jest reportaż, naśladuje literackie formy wyrazu, aby przekonać czytelnika, że to wszystko naprawdę się zdarzyło. Przeciętny czytelnik nie dostrzeże mimetyzmu formalnego i ulegnie urokowi prawdy.

Nie zrobi tego badacz. W dokumencie odkryje on chwyty artystyczne, naśladowanie struktur i stylów literackich, tak jak to zrobił Głowiński, analizując Dokument jako powieść (chodziło o tekst amerykańskiego socjologa Oscara Lewisa Sanchez i jego dzieci), czy ja, pisząc o książce Kazimierza Moczarskiego Rozmowy z katem $^{23}$.

Tutaj sygnalizujemy serię pytań, które musi sobie postawić dzisiaj badacz mimesis. Czy zwrócenie uwagi na mowę jako jej przedmiot jest tożsame z fundowaniem literatury na udawaniu aktów mowy? Czy świadomość pisania nie-serio musi u twórców pociagać za sobą chwyty imitacyjne na poziomie stylu? Czy każdy pisarz imituje mowę, czy tylko chcą to robić pewni pisarze? Czy to znaczy, że ci, którzy tego nie robią, piszą serio?24

Aksjomat filozofów, konstytuujących literaturę na udawaniu aktów mowy, nastręcza trudności nie tylko w analizie stylu, ale w badaniu gry nadawczo-odbiorczej, do której przede wszystkim powinien się stosować.

\footnotetext{
„Poétique” 1997, nr 109 pokazuje, że w tekście Prousta istnieją ślady tego, co Ph. Lejeune uznał za pakt autobiograficzny: 1 . osoba, brak paratekstu „powieśc”, imię narratora. Cytuje najbardziej wieloznaczny fragment, w którym fikcja miesza się z realnością: „Z chwila, gdy odzyskiwała mowę, powiadała: «Mój», albo: "Drogi mój", po czym następowało moje imię, co, w razie gdybym opowiadającemu dał imię autora tej książki, brzmiałoby: «Mój Marcel»" (M. Prou st, W poszukiwaniu straconego czasu, 5, Uwięziona, przeł. T. Boy-Żeleński, Warszawa 1958, s. 77-78).

${ }^{22} \mathrm{Ph}$. Lejeune, Moi aussi, Paris 1986, s. 42.

${ }^{23}$ Por. M. Glowiński, Dokument jako powieść, w: Studia o narracji, red. J. Błoński, S. Jaworski, J. Sławiński, Wrocław 1982; Z. Mitosek, Semantyczne aspekty literatury faktu, (1988), w: Mimesis...

${ }^{24}$ Pewne, bardzo ogólne odpowiedzi można znaleźć w pismach Searle’a: filozof ten podkreśla, że zakresy fikcji i literatury nie pokrywają się: intencją pisarza jest udawanie aktów mowy, ale czytelnik może uznać za literacką każdą wypowiedź pięknie zbudowana, bez względu na to, czy zawiesza ona świat realny, czy teź mówi o rzeczywistości serio. Tu jednak wracamy do jeszcze jednej aporii. Co jest wyznacznikiem literackości: fikcja czy konstrukcja wypowiedzi?
} 
Na odczytaniu wypowiedzi narratora i postaci literackich jako przekazów serio opiera się przecież historia idei. Można by wymienić setki znakomitych książek o literaturze, które pomijają szczególną ramę modalną, przypisaną im przez teoretyków aktów mowy. Ostatnio zrobiła to w swoim referacie badaczka uchodząca za polskiego teoretyka i ideologa dekonstrukcjonizmu ${ }^{25}$.

Wszystkie te pytania prowadzą do wniosku, że literatura jako spektakl mowy jest dla czytelnika spektaklem świata, który owa mowa reprezentuje czy tylko udaje, że reprezentuje. Nie sposób jest pisać o mimesis, pomijając to, co tradycyjna estetyka określała jako naśladowanie, odzwierciedlenie, przedstawienie czy reprezentację rzeczywistości.

W najnowszych badaniach literackich kategoria mimesis bywa zastępowana przez pojęcie przedstawienia. Jednak pojęcie to jest równie niejasne i wieloznaczne jak mimesis. Niektórzy współcześni badacze skłonni są identyfikować te dwa koncepty. Tak postąpili francuscy tlumacze $P_{0}$ etyki Arystotelesa, którzy odpowiednikiem mimesis uczynili représentation, a nie imitation. Z kolei Gérard Genette, któremu zawdzięczamy subtelne analizy mimesis pojmowanej $\mathrm{w}$ sferze lexis, zatem języka, a nie świata przedstawionego (logos), w ostatnich pracach utożsamia Arystotelesowską mimesis z fikcja, czyli „przedstawieniem, a raczej symulacją wyobrażonych działań i wydarzeń" (représentation, ou plutôt de simulation d'actions et d'événements imaginaires ${ }^{26}$.

W języku francuskim wyraz représentation jest homonimiczny: oznacza zarówno unaocznienie jakiegoś obiektu, jak i jego substytucję. W języku polskim owe dwa sensy oddają dwa odmienne wyrażenia: przedstawienie

${ }^{25}$ Chodzi o wykorzystanie wypowiedzi postaci z powieści D. Lodge'a, Maly światek do zilustrowania problemów wspólczesnej refleksji o literaturze w referacie Anny Burzyńskiej, Poststrukturalizm, dekonstrukcjonizm, feminizm, gender, dyskursy mniejszościowe $i$ co dalej? wygłoszonym na konferencji "Sporne i bezsporne problemy nauki o literaturze".

${ }^{26}$ G. Genette w książce: Fiction et diction, s. 17 oraz A ristote, Poétique, traduction et commentaires R. Dupont-Roc i J. Lallot, Paris 1980. Uzasadnione zastrzeżenia wobec tego przekładu zgłosił J.-M. Sch aeffer w książce: Pourqoi la fiction, Paris 1999, s. 15. Pisze on, że decyzja francuskich filologów „ustatycznia” kategorię mimesis, eliminuje z pola widzenia te wszystkie zjawiska, które decydują o podmiotowym i procesualnym charakterze fenomenu i o jego związanym $\mathrm{z}$ odbiorem antropologicznym wymiarze. Odróżnienia mimesis jako procesu i jako rezultatu tego procesu domagał się J. Lalewicz we wzmiankowanym artykule. Warto podkreślić, że mimo odmienności tłumaczeń słowo mimesis nie znika z prac teoretycznych, tyle że zaczyna oznaczać co innego: już nie odpowiedniość wobec świata, ale postawę odbiorcy, który percypuje sztukę w sposób „mimetyczny”, tzn. odnosząc ją do rzeczywistości. 
i reprezentacja (albo przedstawicielstwo). Dlatego zwrot „przedstawienie reprezentuje X" nie jest pleonazmem. Funkcją przedstawienia jest przywołanie tego, co nieobecne. Zastępuje ono dany obiekt ze względu na jakieś cechy; jego odniesienie ma zawsze charakter konwencjonalny. Ta symboliczna funkcja wyklucza w zasadzie problem mimesis; semiotycy mówią o przedstawieniach ikonicznych, podkreślając $\mathrm{w}$ nich aspekty umowności. W ujęciu tradycyjnym liczy się przede wszystkim aspekt przedmiotowy: przedstawienie nie tyle zastępuje, co unaocznia przedmiot, przybliża go, opisuje jego zmysłowy wygląd. W tej funkcji unaocznienie staje się samowystarczalnym obiektem percepcji. Tak mówi się o przedstawieniu w malarstwie i tak chyba należy rozumieć odniesienie tej kategorii do literatury w znanej sentencji ut pictura poesis.

Symboliczny i przedmiotowy aspekt przedstawienia trzeba uzupełnić o jego aspekt podmiotowy, refleksyjny. Obiekt reprezentowany jest przez kogoś i dla kogoś; przedstawienie stanowi więc strukturę intencjonalna, efekt nakierowanej na przedmiot świadomości. Ten podmiotowy aspekt sprawia, że nie będąc ani mimetycznym podwojeniem przedmiotu, ani absolutna prawda, przedstawienie stanowi mediację między świadomością a światem. W ten sposób staje się strukturą rozumienia ${ }^{27}$. Owa ambiwalencja, napięcie między aspektem symbolicznym, przedmiotowym i refleksyjnym określa percepcję dzieł sztuki i decyduje o empirycznym zakotwiczeniu mimesis.

Kategoria przedstawienia wprowadza do problematyki mimesis literackiej trzy nowe kwestie. Jedna - to sposób literackiej reprezentacji, podobieństwa, modelowania, symbolizowania. Druga - to związek przedstawienia z psychiką, usytuowanie tego, co nazywamy obrazami świata czy modelami rzeczywistości w świadomości podmiotów. Trzecia - to problem referencji, odniesienia do rzeczywistości. Pisząc o mimesis jako przedstawieniu, powracamy do opozycji określającej tytuł tej pracy. Podobnie jak w wypadku mimesis mowy, gdzie refleksja nad mimetyzmem formalnym prowadziła do zagadnień szczególnie rozumianej referencji (odniesienie tekstu do realnych praktyk wypowiedzeniowych), a filozofia analityczna skupiała uwagę na literackim udawaniu aktów wypowiadania, tak w wypadku świata przedstawionego w literaturze mówi się o odniesieniu tegoż świata do rzeczywistości od niego niezależnej albo też o udawaniu owego odniesienia, o nastawionym na grę z czytelnikiem efekcie realności.

Roland Barthes, Michael Riffaterre, Philippe Hamon, skupiając uwagę na utworach realistycznych, analizowali mechanizmy udawania, które

${ }^{27}$ Problemy te wnikliwie przeanalizował L. Marin w ksiązce: De la représentation oraz - nawiązując do koncepcji francuskiego teoretyka - M. P. Markowski w książce: Pragnienie obecności, Gdańsk 1999. Por. także nr 1 pisma „Le Romantisme” z 2001 roku, zatytułowany La Représentation. 
sprawiają, że czytelnik odbiera świat wyobrażony w literaturze jako tekstową reprezentację świata obiektywnego. Strategie mimetyczne polegają na selekcji przedmiotów przedstawienia, na prezentacji świata za pomocą stereotypów, klisz i komunałów bliskich mowie czytelnika, na organizacji intrygi zgodnej z potocznymi schematami fabularnymi, a opisów - z utartym obrazowaniem. Literatura jawiła się w tych ujęciach jako sztuka manipulacji, w grze $\mathrm{z}$ czytelnikiem autor miałby być tym graczem, który wie lepiej i trzyma w zapasie dodatkowe karty. Lektura jest odczytywaniem tekstu jako przekazu przezroczystego, bez postrzegania pokładów sztuczności, które rządzą tyleż wypowiedzią, co światem w niej przedstawionym. Mimesis nie stanowi rezultatu mathesis, czyli wiedzy o świecie, ale semiosis - procesu znaczeniotwórczego, oddalającego tekst od realności, o reprezentacji której myśli naiwny czytelnik. W radykalnej wersji (którą przedstawił Barthes w Dyskursie historii) mówi się, że efekt mimetyczny nie ogranicza się do literatury; podlegają mu także teksty ukierunkowane na głoszenie prawdy, jako że o każdym typie referencji decydują językowe i ponadjęzykowe kody znaczeniowe, kamuflujące świat rzeczywisty $^{28}$.

Opisywane ujęcia głosiły nieprzydatność kategorii mimesis; pojmowanie komunikacji jako nieskończonej semiozy kończyło się odrzuceniem przekonań o referencyjnej funkcji literatury. Efekt realności to mechanizm semiotyczny, który prowadzi do zatarcia mediacji i do dezintegracji znaku jako śladu obecności. Jeżeli mimesis jest relacją przedmiotowo-podmiotowa, to w efekcie realności znika podmiot i przedstawienie, pozostaje sam przedmiot, a właściwie tylko jego iluzja ${ }^{29}$. To, co estetyka oraz teoria aktów mowy określały jako „zawieszenie świata”, interpretowano tu jako jego niekończące się odsunięcie, czy wręcz nieobecność. I tak dochodzimy do stadium kryzysu „mimetycznego”, który ogarnął wspólczesną filozofię i naukę o literaturze.

${ }^{28}$ Por. R. Barthes, $S / Z$ (1970), przel. M. P. Markowski, Warszawa .1999. „Artysta "realistyczny" nie umieszcza u źródeł swego dyskursu "rzeczywistości», lecz tylko, na tyle daleko, na ile jest to możliwe, rzeczywistość już zapisaną, kod prospektywny, wzdłuż którego, jak okiem sięgnąć, ciagnie się jedynie amfilada kopii” (s. 208); R. Barthes, Dyskurs historii (1967), przel. A. Rysiewicz i Z. Kloch, „Pamiętnik Literacki” 1984, z. 3: „Innymi słowy to, co w historii "obiektywne" określone jest jako "realne», stanowi zawsze nie sformulowane signifié, ukryte za pozorną wszechmocą widocznego desygnatu. Sytuacja taka okresla to, co można by nazwać efektem realności" (s. 295). Pomijamy krytykę ideologii, której dokonywali bađacze głosów opinii publicznej, dyskursów społecznych i językowych artykulacji aparatów władzy, pomijamy cały nurt socjokrytyki. Nacechowanie krytyczne teorii, jej zaangażowanie rewolucyjne prowadziło do odrzucenia literatury realistycznej. Pożądanym modelem literatury stała się proza demaskująca stereotypy i kwestionująca utarte punkty widzenia.

${ }^{29}$ Por. krytykę uzasadnienia „efektu realności” w książce: C. Bremond, Th. Pavel, De Barthes à Pavel. Fictions d'un critique, critique d'une fiction, Paris 1998, s. 45-54. 
Jak każdy kryzys, ma on charakter paradoksalny: filozoficzna nieufność do mimesis idzie w parze $\mathrm{z}$ nadużywaniem tej kategorii $\mathrm{w}$ tekstach krytycznych; naukowa bezradność w jej interpretacji nie pozostaje w żadnym stosunku wobec nasilenia się postaw mimetycznych w kulturze masowej, do wszechwładzy symulakrów, w końcu do literatury autorefleksyjnej, która akty mimesis fikcjonalizuje. Ponadto, eliminując problem mimesis jako intencji autorskiej i jako semantyki tekstu poststrukturalistyczni krytycy tej kategorii nie mogą zakwestionować faktu, że lektura jako taka polega na niezupełnym zawieszeniu rzeczywistości, że stanowi ona grę między pragnieniem fikcji a pragnieniem referencji ${ }^{30}$.

Odrzucenie referencji można traktować jako przerzucenie jej na wyższy poziom: tekst literacki naśladuje bowiem nie świat, ale głosy opinii publicznej (Arystotelesowska doxa), mity, inne teksty; odniesienie wypowiedzi literackiej stanowiłyby zatem wytworzone przez człowieka reprezentacje rzeczywistości. Niewątpliwym efektem poznawczym opisywanej refleksji było zwrócenie uwagi na działanie mediacji o charakterze wyobrażeniowym, które określają proces pisarstwa i lektury ${ }^{31}$.

Można powiedzieć, że po raz drugi dokonało się przesunięcie przedmiotu mimesis: w pierwszej części stwierdziliśmy, że jej obiektem - w miejsce naśladowanej rzeczywistości - stała się praktyka językowa. Teraz - ponad czy pozajęzykowe systemy przedstawień, które - bez względu na genezę (mityczną, religijną, ideologiczną, literacką czy psychiczną) -osadzone są w doświadczeniu osobników zaangażowanych w grę literacką. Owo podwójne przemieszczenie zdaje się w nieskończoność odsyłać stary aksjomat o naśladowaniu rzeczywistości w literaturze. Jeżeli mówi się o analogiach, to pojawiają się one między światem przedstawionym w sztuce a reprezentacjami mentalnymi nabytymi w percepcji i edukacji ${ }^{32}$. Jed-

${ }^{30}$ Por. wypowiedź J. Derridy w wywiadzie: Ta dziwna instytucja zwana literaturą: „W każdym razie tekst sam z siebie nie potrafi uniknąć poddania się lekturze «transcendentnej». Literatura, która zakazywałaby takiej lektury, niweczyłaby samą siebie. [...] Każdy tekst literacki odgrywa i negocjuje zawieszenie referencjalnej naiwności, referencjalności "tetycznej" (a nie referencji lub odniesienia intencjonalnego w ogóle), [...] literatura mówiąca wyłącznie o literaturze albo też dzieło wyłącznie autoreferencjalne niezwłocznie unicestwiłyby same siebie" (s. 191-193). Kategorię „Zawieszenia rzeczywistości" przejął Derrida od Husserla.

${ }^{31}$ Por. R. Nycz, Literatura postmodernistyczna a mimesis, w: Tekstowy świat, a także rozdział Koniec mimesis? z mojej książki.

${ }^{32} \mathrm{Na}$ temat związku sztuki z przedstawieniami mentalnymi zob. M. Denis, Image et cognition, Paris 1989, zwlaszcza strony 211-213; G. Denhiere, Il était une fois, Lille 1984; J. M. Sch aeffer, Les Célibataires de l'art; Paris 1996. Definicje przedstawień mentalnych i ich psychologicznych modeli daje L. Diguer w książce: Schéma narratif et individualité, Paris 1993. Por. także F. Rastier, Principes et paradigmes de la recherche cognitive, „Semiotica" 1989 , z. 1/3. Kategoria znana z filozofii empirycznej (Locke, Hume, Berkeley), rozwijana w estetyce pod nazwą "wewnętrznych oglądów", w psychologii kognitywistycznej uległa istotnej transformacji: nie chodzi o zbiór obrazów, przedstawienie mentalne jest 
nak, wbrew teoretykom efektu realności, można spotkać badaczy, którzy - zainspirowani kognitywizmem - twierdza, że struktury mentalne sa izomorficzne wobec świata obiektywnego, że świadomość stanowi odwzorowanie rzeczy i stanów rzeczy, co w konsekwencji przywraca pytanie o referencyjna moc literatury. Koncepcji tych dotychczas nie brałam pod uwagę i dlatego chciałabym im poświęcić ostatnią część rozprawy.

W ujęciu literatury jako gry odróżnia się fikcje aktywne, związane z wyobrażeniem, twórczością i zabawą, od odbioru fikcji artystycznych, w którym przedstawienia twórcze wchodzą w interakcję z sytuacją lektury. Mimemy - bodźce produkowane przez tekst - spotykają się z przedstawieniami mentalnymi pochodzącymi z doświadczenia przeszłości. Tu właśnie jest generowana relacja podobieństwa: łączy ona percepcję $\mathrm{z}$ wiedzą, wyobrażenie artystyczne $\mathrm{z}$ osobniczą encyklopedią ${ }^{33}$. Jej źródło jest podmiotowe, a nie przedmiotowe. Przedstawienia literackie wywołują postawę identyfikacji emocjonalnej (empatii), która może dotyczyć w równej mierze bohaterów, ich losów, jak i artystycznych punktów widzenia. Wiąże się to z tezą, że rzeczywistość nie jest układem obiektywnych faktów i przedmiotów, ale ich doświadczeniem przez podmiot. W ujęciach „antymimetycznych" doświadczenie to, zastępując rzeczywistość, wytwarza iluzję realności; dla zwolenników referencyjnej koncepcji mimesis stanowi ono twarde jądro rzeczywistości samej, do której odnoszona jest literacka fikcja ${ }^{34}$. Mimesis byłaby tu jednym z powszechnych, chociaż indywidualnie zdeterminowanych sposobów akcesu do świata.

całością treści poznawczych konstruowaną na podstawie informacji pochodzących z rzeczywistości (percepcja) i wiedzy aktywizowanej w trakcie obróbki poznawczej tego przedstawienia (przypomnienie i wnioskowanie).

${ }^{33}$ A. Falkowski w studium: Relacja podobieństwa $w$ procesach poznawczych. Ekologiczne $i$ informacyjne podejście $w$ psychologii, RW KUL, Lublin 1990, pisze, że podobieństwo jest to „relacja między dwoma lub więcej obiektami, której źródła znajdują się poza obiektywnie istniejącym źródłem obiektów, jak również poza określoną w danym momencie do reagowania dyspozycją psychiczną organizmu. Należy ich szukać w sytuacji środowiskowej, w sposób lączący przystosowawcze, a więc motywacyjne funkcje człowieka. Określone podobieństwo można więc także rozumieć jako behawioralny wskaźnik podstawowej funkcji motywacyjnej człowieka, jaką jest potrzeba najlepszej adaptacji do środowiska, wyznaczany wewnętrznym schematem odpowiadajacym danemu fragmentowi rzeczywistości" (s. 17). Cytat ten zaczerpnęliśmy ze studium J. Ślós arskiej, W kierunku nieliniowych modeli techne i poiesis, w: Rozważania metodologiczne, pod red. E. Kasperskiego, Warszawa 2000 , s. 157.

${ }^{34}$ Stanowisko takie reprezentuje J.-M. Schaeffer w książce: Pourquoi la fiction? Analizę "pogrążenia mimetycznego" (immersion mimétique) referujemy za tą książką. Por. rozdział: La phylogenèse de la fiction: de la feintise ludique partagée. M. Denis (op. cit., s. 211-213)) pisze, że „obraz wytworzony na podstawie dyskursu posiada cechy strukturalne podobne do obrazów wytwarzanych w percepcji; zaletą poznawczą przedstawienia literackiego jest dostarczenie czytelnikowi niejęzykowego modelu tekstu, którego struktura oraz reguły odbioru są podobne do reguł zdarzeń percepcyjnych". Por. także J.-L. Dufays, Stéréotype et lecture, Liege 1994. 
Wszystkich badaczy fikcji łączy założenie, że percepcja dzieła artystycznego jest aktem spontanicznym, zaczyna się poza świadomością i rzadko osiąga stadium przekonań i twierdzeń. Jednakże pewni z nich, tacy jak Ingarden, Gombrich, a także Derrida twierdzą, że zainteresowanie sztuką zawiesza zainteresowanie światem. Stan zanurzenia mimetycznego, pogrążenia się $w$ fikcji zdaje się być przeciwieństwem lektury tranzytywnej, przekraczającej swoistość świata przedstawionego w kierunku świata realnego. Inni - jak Sartre, Łotman, Schaeffer - uważają, że skupienie uwagi na przedstawieniu nie wyklucza pytań o odniesienie. Jedno jest pewne: przy założeniu, że rzeczywistość jest światem osobniczego doświadczenia, żaden $\mathrm{z}$ teoretyków fikcji nie jest w stanie udowodnić, iż czytelniczemu pragnieniu referencji odpowiada odniesienie tekstu literackiego do świata rozumianego fizykalnie ${ }^{35}$. Urok mimesis polegałby na ambiwalencji pragnienia i odmowy: na poziomie emocjonalnej lektury pogrążamy się w świecie fikcji jak w świecie rzeczywistym. W fazie świadomej percepcji dostrzegamy, że to tylko fikcja ${ }^{36}$.

Referowana teoria pogrążenia mimetycznego ma kilka mankamentów. 1. Nie jest w stanie wyjaśnić tych lektur, które polegają na asymetrii przedstawienia literackiego i systemu przedstawień mentalnych danego czytelnika (grupy czytelników, klasy itp.). 2. Wywiedziona częściowo z dawnych pikturalnych koncepcji literatury, które także posługiwały się kategoriami obrazów mentalnych, nie jest w stanie określić lektury jako doświadczenia fabuły $\mathrm{i}$ wyborów fabularnych. 3 . Mimo że rezygnuje $\mathrm{z}$ traktowania literatury jako generatora iluzji referencjalnej, w zasadzie nie zajmuje się prawdą oraz referencją pojmowaną jako odniesienie do świata rzeczywistego, a nie jako osobnicze doświadczenie świata.

Pierwszy brak rekompensuje jakoś teoria światów możliwych, chociaż niektórzy z jej zwolenników, jak np. Ludomir Doležel, w ogóle rezygnują z posługiwania się kategorią mimesis ${ }^{37}$. Inni badacze, jak np. Eco, anali-

${ }^{35}$ F. Diguer (Schéma narratif et individualité) twierdzi, że sama kategoria „przedstawień mentalnych” jest hipotezą - nie daje się ich empiryczne „dotknąć”, tak jak np. dotyka się tekst językowy; o ich egzystencji wnioskujemy na podstawie schematów poznawczych i modeli percepcyjnych formułowanych przez psychologię. Wydaje się, ze niemałą przysługę psychologii oddała tu literatura wraz z tekstami artykułującymi (czy tylko naśladującymi?) strumień świadomości oraz monolog wewnętrzny.

${ }^{36}$ Semantyczną ambiwalencję lektury dzieł literackich niezwykle wnikliwie opisał R. Ingarden w rozprawie $O$ tzw. "prawdzie" $w$ literaturze, w: Studia $z$ estetyki, t. I, Warszawa 1959. O wiele później pisal o tym Walton nazywając mimesis 'make-believe'.

${ }^{37}$ W rozprawie La construction de mondes fictionnels à la Kafka, „Littérature” 57, 1985 L. Doležel stwierdza, że światy możliwe (uniwersa mityczne, oniryczne, religijne, światy patologiczne wytwarzane przez chorobę) jako motywacja światów fikcyjnych są w stanie dostarczyć narzędzi do badania każdej literatury, także literatury fantastycznej. Tak czytelnik odbiera rzeczywistość przedstawioną w opowiadaniach Kafki, których odnie- 
zują różne typy encyklopedii pisarza i czytelnika, które to pojęcie coraz częściej zastępuje kategorie kodów nadania i odbioru ${ }^{38}$.

Zagadnienia prawdy i odniesienia literatury do świata obiektywnego usiłowały rozwiązywać różne teorie modelowania artystycznego ${ }^{39}$. Wspólną ich cechą jest przekonanie, że model nie naśladuje, ale odtwarza strukturę przedmiotu. Odróżnia się typowe dla nauki modele homologiczne, zawierające przedstawienia referencyjne od modeli fikcyjnych, wytwarzających w umyśle czytelnika reprezentacje mentalne (mimemy). Jak twierdzą neurosemiotycy, kategorie podobieństwa i analogii mają osadzenie w strukturze mózgu; one to właśnie decydują o percepcji dzieł sztuki, która - bez względu na intencję twórczą - w pierwszej fazie polega na szukaniu mimetycznych „przynęt”. W fazie twórczości literatura modeluje treści, które podmiot w aktach świadomości przyswaja sobie pod postacią różnego typu przedstawień. Wywodzące się z fenomenologii założenie, że cechą świadomości jest intencjonalność, nakierowanie na świat nas otaczający, może prowadzić do wniosku, że jej treści, nawet gdy mają charakter czysto wyobraźniowy, są do tego świata ograniczone. Kompetencje przedstawieniowe polegają na tematyzacji rzeczywistości, a zawartość fikcji jest egzemplifikacją tego, co ta rzeczywistość zawiera. W tym sensie fikcje artystyczne, bez względu na ich konstrukcję, podlegają prawu globalnej analogii ze światem, który prezentuje się w osobniczym doświadczeniu ${ }^{40}$.

sienie do świata aktualnego prowadzi interpretację na manowce. Zerwanie z potocznym rozumieniem mimesis jako odtwarzania realnego świata na rzecz „semantyki konstrukcjonistycznej" nie oznacza więc odrzucenia zagadnień referencji, co odcinający się od strukturalistów Doležel wielokrotnie podkreśla. Lektury niemimetyczne naznaczone są wysiłkiem poznawczym, który kieruje się na ogarnięcie procesów twórczych człowieka.

${ }^{38}$ Kategorią encyklopedii posługują się D. Sperber oraz D. Wilson w książce: Relevance Communication and Cognition, przekł. franc. A. Gerschenfeld et Dan Sperber, La Pertinence, Paris 1989. Praca językoznawców kognitywnych dotyczy procesów nabywania oraz akumulacji informacji. Piszą oni, że „o wartości interpretacji decyduje kontekst, na który składa się wiedza pochodząca $\mathrm{z}$ encyklopedii, a nie $\mathrm{z}$ bezpośredniego doświadczenia świata" (s. 277). Badacze ci definiują język jako system przedstawień, a nie jako układ różnic. Przedstawienia mentalne uzyskują formę obiektywną w strukturach językowych; cechą przedstawienia literackiego jest podwójna reprezentacja, czyli interpretacja jednej wypowiedzi przez inną, ją przytaczającą.

${ }^{39}$ Modele fikcyjne buduje fizyka i matematyka, nauki, które zdając sobie sprawę z podmiotowych ograniczeń poznania, nie rezygnują z celu, jakim byłaby adekwatność modelu wobec rzeczywistości. O takiej adekwatności, która byłaby jakąś wersją referencji, mówią anektując kategorię modelowania badacze sztuki. Por. L. Nowak, Gombrowicz - czlowiek, Poznań 2000.

${ }^{40}$ Por. Schaeffer, op. cit., s. 220-225. Takie ujęcie pozostawałoby w zgodzie z inną decyzją interpretacyjną, też dotyczącą semantyki. Chodzi o stosunek mimesis i izomorfizmu. Jeśli kategorię mimesis określimy jako odpowiedniość struktur, wówczas problem podobieństwa przesuniemy i rozszerzymy o bardzo rozlegle dziedziny. Jak pamiętamy, R. Jakobson mó- 
Różnice między dyskursem mimetycznym a dyskursem „prawdziwościowym" polegałyby na odmiennym statusie modalnym, na świadomości istnienia prefiksu ,jak gdyby”, „niby”, „quasi”. Nie zmienia faktu, że treściowe uposażenie przedmiotów fikcyjnych ma charakter analogiczny do przedmiotów realnych, a całość świata przedstawionego podlega prawom koherencji, znanej ze świata, który nas otacza. Stąd płynie wrażenie prawdy, trafności, odpowiedniości. Weryfikację referencyjną zastępuje konsekwencja przedmiotowa.

W ten sposób kognitywistyczne interpretacje lektury nakładają się na rozstrzygnięcia fenomenologii, która przecież starannie się izolowała od analiz świata mentalnego. Odrzucona przez fenomenologów referencja wraca tylnymi drzwiami: na zasadzie analogii między zawartością przedmiotową świata przedstawionego a mentalnym doświadczeniem świata rzeczywistego. Pragmatyczna teza o mimesis jako udawaniu aktów mowy czy fingowaniu sądów zyskuje potwierdzenie w analizie literackiego odniesienia. Opiera się ono jednak na szczególnym, na ogół związanym ze sztuką realistyczną aksjomacie: że fikcyjne reprezentacje nie są w stanie przekroczyć osobniczego zetknięcia się świadomości z rzeczywistością ${ }^{41}$.

Te ograniczenia teorii nie muszą być jej mankamentem. Ich konsekwencją jest ograniczenie zakresu mimesis w literaturze do twórczości odpowiadającej potocznemu doświadczeniu odbiorcy, która - nawet jeżeli to doświadczenie przekracza - $w$ akcie transgresji odwołuje się zawsze do tego, co stałe, dawne, utrwalone. Być może, uda się w ten sposób oddzie-

wił o diagramatyczności każdej możliwej wypowiedzi językowej. Czy zatem można uznać model izomorficzny za diagram, czyli ikonę relacji? W ujęciu semiotycznym podobieństwo traci wymiar materialny, niemniej jednak pozostaje relacją motywowaną przez cechy przedmiotu odtwarzanego i odtwarzającego. W ten sposób wracamy do naszych starych dylematów (por. moją książkę) i uzasadniamy globalną koncepcję mimesis w literaturze, włączając do jej charakterystyki właściwości takie, jak izomorfizm, ikoniczność, diagramatyczność. Warto wspomnieć, że tak właśnie, w odniesieniu do nawyków przedstawieniowych pojmuje ikoniczność literatury J. Łotman w Strukturze tekstu artystycznego - dziele często cytowanym w zachodniej teorii literatury i estetyce. Ale semiotyk interesuje się o wiele bardziej procesami modelowania artystycznego, które interpretuje w kategoriach poetyki, aniżeli mentalnymi podstawami percepcji sztuki.

${ }^{41}$ Schaeffer powołuje się na prace Genette'a i Herrnstein-Smith; pisząc o intencjonalności, cytuje Searle’a. Zdaje się być zupełnie nieświadomy faktu, że tezy przezeń głoszone mają odpowiedniki w Ingardenowskiej teorii dzieła literackiego i teorii fikcji jako takiej. Warto tylko podkreślić, że Ingarden, który nie interesował się referencją w literaturze, a nawet był zdecydowanym wrogiem takiego podejścia do sztuki, kategorię „prawdziwości” pojmował jako efekt artystyczny, jako trafność wypowiadanej przez podmiot liryczny sentencji czy też jako konsekwencję przedmiotową wewnątrz czysto intencjonalnego, a więc ukonstytuowanego w świadomości - świata utworu literackiego. Pisał jednak o analogiach między materialno-treściowym uposażeniem przedmiotów czysto intencjonalnych a własnościami przedmiotów rzeczywistych. Por. R. Inga rde n, O dziele literackim, przeł. M. Turowicz, Warszawa 1960, s. 239. 
lić literaturę „niemimetyczną”, autoreferencjalną, czyli taką, która jest ideałem filozofów i krytyków wieszczących koniec naśladowania ${ }^{42}$.

Jeśli chodzi o zarzut, że teorie kognitywistyczne prowadzą do pikturalnej koncepcji sztuki, to jest on do odparcia w dwojaki sposób. Psychologia kognitywna mówi nie tyle o przedstawieniach, co o modelach percepcyjnych przedmiotu oraz schematach mentalnych, które mają na ogół charakter narracyjny. Odniesienie do nich pozwala na wpisanie nowych doświadczeń i projektów działania w ramy znane indywiduum od dawna. Schematy narracyjne pośredniczą między zachowaniem jednostki a światem odeń niezależnym, stanowiąc podstawowe struktury rozumienia, także rozumienia tekstów literackich, czynnik przyswojenia nieznanych treści oraz generator projektów zachowań. W tym sensie mają one niewiele wspólnego z opisywanymi przez dawne estetyki „oglądami wewnętrznymi" czy obrazami w naszych głowach. Nie rozwijając tego tematu, warto także podkreślić, że psychologia kognitywna i oparta na niej estetyka zupełnie nie interesują się sprawami, które fascynowały badaczy efektu realności, mianowicie ideologicznym charakterem mediacji. Schematy mentalne maja egzystencję uniwersalna, stanowia ponadhistoryczne wyposażenie mózgu. To, co teoretycy iluzji referencjalnej traktowali jako czynnik kłamstwa, ułudy, marząc o istnieniu granicy, którą być może gdzieś, kiedyś - istniejąca „naga rzeczywistość” (kantowska „rzecz sama w sobie"?), kognitywiści traktują jako twarde jądro doświadczenia, powszechne, choć indywidualnie zdeterminowane struktury, na które nakładają się jakieś historyczne uwikłania. Dla problematyki mimesis istotne jest założenie o istnieniu analogii między organizacją schematów mentalnych a organizacją rzeczywistości, czego przykładem jest np. twierdzenie, że opowiadanie jest poznawczą strukturą tego, co przeszłe ${ }^{43}$.

${ }^{42}$ J. Derrida w cytowanym wywiadzie twierdzi, że dyskurs literacki jest jedynym typem wypowiedzi, który potrafi fikcjonalizować własną sytuację. Oczywiście nie każdy dyskurs literacki - wbrew przytoczonej wcześniej tezie, że literaturą może stać się wszystko, Derrida pisze o tekstach, a raczej „zdarzeniach tekstualnych”, które ze względu na szczególną budowę mocniej opierają się lekturom transcendentnym. W terminologii tutaj omawianej można by powiedzieć, że poezja Pounda czy proza Bataille’a w ogóle uniemożliwiaja „mimetyczne zanurzenie”.

${ }^{43}$ Por. J. Trzebiński, Narracja jako sposób rozumienia świata, w: Praktyki opowiadania, red. B. Owczarek, Z. Mitosek, W. Grajewski, Kraków 2001; L. Diguer, Schéma narratif et indiuidualité; także zbiór rozpraw: Narrative psychology: the storied nature of human conduct, ed. T. Sarbin, New York 1986; Kognitywizm wywodzi się również z językoznawstwa; definiując język jako system przedstawień, lingwiści podkreślają, że „Słowa nie odwzorowują rzeczy "fotograficznie», lecz raczej "portretują" je mentalnie" (J. Bartmiński, Perspektywa, punkt widzenia, jezzykowy obraz świata, w: Jezykowy obraz świata, red. J. Bartmiński, Lublin 1990, s. 91. Punkt widzenia jako czynnik podmiotowo-kulturowy decyduje nie tylko o konotacji słowa, ale o kategoryzacji przedmiotu. Por. także E. Tabakowska, Gramatyka i obrazowanie, Kraków 1995. 
Refleksja nad opowiadaniem jako uniwersalnym schematem reprezentacji zbliża psychologów kognitywnych i badaczy literatury, a zarazem uwalnia teorię mimesis od obciążeń „pikturalnych”. Opowiadanie nie jest konwencją przedstawieniową, odpowiada ono - jak mówi Claude Bremond - ogólnej logice działań ludzkich ${ }^{44}$. Z kolei Paul Ricoeur twierdzi, że struktura narracji jest izomorficzna wobec temporalnej struktury rzeczywistości. W ten sposób koncepcja mimesis krzyżuje się z antropologią opowiadania.

Wbrew tezom o braku substancjalnych wyznaczników literackości, zwolennicy referencyjnej funkcji literatury pytają, na czym polega swoistość mimetycznego przedstawienia (poza tym, że jest ono reprezentacją analogiczną, określoną przez status ,jak gdyby"?). Warto przypomnieć Ricoeurowską interpretację Poetyki Arystotelesa: filozof pisze, że fabuła tragiczna przedstawia działania ludzkie, nadając im status ogólności, że $\mathrm{w}$ ruchu artystycznej mimesis literatura porządkuje to, co w rzeczywistości niespójne, rozproszone, wielokierunkowe. Zaś tematyzacja fikcyjna, oparta na modelu cierpienia i działania ${ }^{45}$ jest czymś więcej, niż tylko regułą narzuconą chaosowi faktów; jako aktywność podmiotu stanowi element rozumienia świata, procesu, w którym mimesis odgrywa niepoślednią rolę.

Widzimy, że w udowadnianiu referencyjnej funkcji literatury łączą się różne metody i metodologie: lingwistyka $\mathrm{z}$ hermeneutyką, kognitywizm $\mathrm{z}$ narratologią i antropologia, a wszystko to podprawione jest ostrym sosem sceptycyzmu, który wnosi koncepcja mimesis jako udawania. Konkluzja jest mało odkrywcza: w dyskursie mimetycznym, udającym coś, czego nie ma czy - łagodniej (i po Arystotelesowsku) - czego nie było, znajdujemy znaki, które służą rozpoznaniu i opanowaniu faktycznego .świata. "Znajdujemy” - pierwsza osoba w tym stwierdzeniu wskazuje na fakt, że znaki te są do odkrycia i że jawią się one tylko podmiotowi, który chce je odkryć.

Uogólniając: proces pragmatyzacji mimesis w badaniach literackich wydaje się nieodwracalny; nawet jeśli założymy, że podobieństwo ma obiektywne wykładniki w funkcjonowaniu mózgu, to jego konstatacja nie może się odbyć bez aktywności osobnika tym mózgiem się posługującego. Referencja w literaturze jest efektem podmiotowym, rezultatem lektury z jej czasowymi, społecznymi i psychicznymi uwarunkowaniami. Badać taką referencję byłoby bardzo trudno, bowiem przedtem trzeba by rozstrzygnąć, czy w ogóle tekst będący przedmiotem tej lektury jest dla czytającego literaturą.

\footnotetext{
${ }^{44}$ Por. C. Bremond, Logique du récit, Paris 1973.

${ }^{45}$ Por. P. Ricoeur, Temps et Recit, t. I, Paris 1983, s. 57-59.
} 
Jednak, po morderczych trudach, jakie doprowadzily mnie do zakończenia tego, co z Witkacowską ironią można nazwać „hauptwerkiem”, pozwolę sobie na znoszącą aporie utopię. Mimesis, zawieszona między udawaniem a referencja, stanowi fenomen nieuchwytny, nie dlatego jednak, że nie jesteśmy w stanie określić jej obiektywnych, namacalnych śladów, ale dlatego, że realizuje się ona na wielu poziomach reprezentacji, i że przechodząc na wyższy poziom, burzy porządek niższego, sieje chaos i niepewność w tym, co już wiemy, na korzyść tego, co po przeczytaniu książki z naszą wiedzą robimy. Grając na naszych przedstawieniach, wprowadzając nas w stan iluzji, wahania i bezradności, udając i produkując symulakry, poprzez swoją grę zakłóca utarty porządek rzeczy na korzyść niekończącego się poznania - także poznania samej mimesis. 